\title{
ANALISIS PERFORMANSI ALGORITMA PENJADWALAN LOG RULE DAN FRAME LEVEL SCHEDULE SKENARIO MULTICELL PADA LAYER MAC LTE
}

\author{
Ridwan*, Indrarini Dyah Irawati, Ridha Muldina Negara \\ Jurusan Teknik Telekomunikasi, Fakultas Teknik Elektro,Universitas Telkom \\ *Corresponding author, e-mail : ridwanchaerawan@gmail.com
}

\begin{abstract}
Abstrak - Teknologi telekomunikasi selular berkembang guna mendukung layanan triple play yaitu voice, data, dan video yang lebih baik kepada pengguna jasa telekomunikasi. LTE (Long Term Evolution) adalah suatu jaringan berbasis IP (Internet Protokol) yang distandarisasi oleh 3GPP ( $3^{\text {rd }}$ Generation Partnership Project). Untuk mendukung hal itu, LTE memerlukan suatu mekanisme yang dapat mendukungnya. Salah satunya dengan menerapkan metode penjadwalan paket di tiap layanan. Penjadwalan adalah perlakuan terhadap paket yang datang sesuai dengan prioritas dari masing-masing algoritma penjadwalan. Pada penelitian ini, menganalisis performansi LTE dengan parameter Delay, Packet loss, Throughput dan Fairness Index menggunakan algoritma penjadwalan FLS (Frame Level Schedule) dan Log Rule pada LTE-Simulator dengan skenario menggunakan trafik VoIP, Video dan BE (Best Effort). Hasil yang didapatkan adalah penjadwalan algoritma FLS lebih baik dibandingkan Log Rule dalam hal throughput sedangkan penjadwalan algoritma Log Rule lebih baik dibandingkan FLS dalam hal delay berdasarkan perubahan jumlah dan kecepatan user di setiap layanan real time. Hal ini menandakan kedua algoritma ini sangat cocok digunakan untuk jaringan LTE dengan kondisi trafik layanan real time, tetapi tidak untuk layanan seperti non real time yakni BE.
\end{abstract}

Kata Kunci : LTE, Scheduling, QoS, layanan triple play, Log Rule dan FLS.

\begin{abstract}
Mobile telecommunications technology gradually evolved to support better services such as voice, data, and video to users of telecommunications services. LTE (Long Term Evolution) is a network based on Internet Protocol (IP) standardized by $3^{\text {rd }}$ Generation Partnership Project (3GPP). To support it, LTE requires a mechanism that can support. One of them by applying methods of scheduling packets in each service. Scheduling is a different treatment to packets that come in accordance with the priorities of the scheduling algorithm. In this research, to analyze the performance of LTE with paramater delay, packet loss ratio, throughput and fairness index uses a scheduling algorithms Frame Level Schedule (FLS) and Log Rule on LTE-Simulator with scenarios using Voip traffic, Video and Best Effort (BE). The results is scheduling algorithms FLS is better than log rule in term of throughput values, while of scheduling algorithms log rule is better than FLS in terms of delay based on the number and speed of the users. This indicates that both scheduling algorithms suitable for use in LTE networks within conditions of traffic real time services, but not for non real time services such as BE.
\end{abstract}

Keywords LTE, Scheduling, QoS, Triple Play Services, Log Rule dan FLS.

Copyright ( 2016 JNTE. All rights reserved

\section{PENDAHULUAN}

Teknologi telekomunikasi selular berangsur-angsur berkembang guna mendukung layanan yang lebih baik kepada pengguna jasa telekomunikasi pada era sekarang. Hal ini sesuai dengan tuntutan pelanggan yang menginginkan bermacam-macam jenis layanan yang dapat di akses dalam satu platform tertentu, seperti layanan triple play yang merupakan layanan suara, data, dan video.
Perkembangan layanan ini menjadi salah satu motivasi pengembangan long term evolution oleh 3GPP ( $3^{\text {rd }}$ generation partnership Project).

Dalam penelitian sebelumnya telah dilakukan beberapa penelitian oleh Stefano, R. (2014) tentang Analisis Perbandingan Kinerja Algoritma Penjadwalan EXP/PF (Exponential/ Proportional Fair), PF (Proportional Fair), dan FLS namun hanya pada Kasus Single Cell Jaringan LTE$^{[1]}$ sedangkan penelitian yang penulis lakukan adalah pada skenario multicell, 
selain itu juga ada penelitian oleh Amatullah, S. K. (2012) tentang Analisis Perbandingan Algoritma Penjadwalan PF dan MLWDF (Modified Largest Weighted Delay First) Pada Kasus Multicell Jaringan Long Term ${ }^{[2]}$. Algoritma penjadwalan yang diteliti hanya mempertimbangkan faktor throughput dan fairness untuk user tanpa memperhatikan jenis trafik yang dilewatkan ${ }^{[3][1]}$. Padahal, tidak semua user membutuhkan throughput yang sama besar. Yang dibutuhkan adalah kesesuaian pengendalian delay untuk masing-masing user dengan tetap memperhatikan batasan throughput ${ }^{[12]}$. Dengan adanya algoritma penjadwalan yang tepat, QoS (Quality of Services) dapat dijamin oleh jaringan.

Berdasarkan penelitian diatas, penulis melakukan penelitian lanjutan yaitu menganalisis performansi penjadwalan algoritma $\log$ rule dan frame level schedule dengan skenario perubahan jumlah user 25, 50, 75, 100 dan kecepatan user 3, 30, $120 \mathrm{~km} / \mathrm{jam}$. Algoritma Log rule (LR) dan Frame Level Schedule (FLS) ini adalah pengembangan dari algoritma proportional fair (PF). Pada penelitian sebelumnya, algoritma proportional fair (PF) tidak begitu baik dalam menangani paket berbasis real time, karena dalam perhitungan matriknya tidak disertakan perhitungan yang melibatkan parameter paket real time seperti max. delay yang ada pada paket layanan real time $^{[2][1]}$. Hal ini yang melatarbelakangi terbentuknya algoritma log rule dan frame level schedule (FLS) karena kemampuan yang baik dalam menangani ciri paket real time yakni sensitive terhadap delay. Performansi kedua algoritma tersebut dianalisis menggunakan simulator LTE-Sim dengan menghitung parameter QoS yaitu delay, packet loss ratio, throughput, dan fairness index.

\section{DASAR TEORI}

\subsection{Pengertian LTE}

LTE adalah suatu teknologi seluler dengan arsitektur berbasis IP yang distandarisasi oleh $3^{\text {rd }}$ Generation Partnership Project (3GPP) ${ }^{[4]}$. Evolusi Jaringan dapat dilihat pada Gambar 1.

Tujuan utama dari pengembangan LTE adalah untuk meningkatkan performansi jaringan sehingga meningkatkan kepuasan pelanggan dan untuk mengkonvergensikan jaringan-jaringan yang sudah ada sehingga bisa saling terkoneksi dengan mudah.

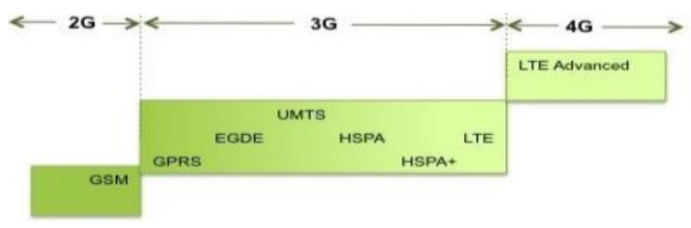

Gambar 1. Evolusi Jaringan ${ }^{[9]}$

Keuntungan yang diharapkan dari LTE antara lain adalah throughput yang tinggi, latency yang rendah, peningkatan kepuasan pelanggan dan arsitektur jaringan yang sederhana $^{[4]}$. Karakteristik LTE dapat dilihat pada Tabel 1 .

Tabel 1 Karakteristik LTE ${ }^{[3]}$

\begin{tabular}{|c|c|c|c|}
\hline Cell Radius & $\begin{array}{c}\text { Up to 5 } \\
\mathrm{km}\end{array}$ & Mobility & $\begin{array}{c}\text { UP to } 350 \\
\mathrm{~km} / \mathrm{h}\end{array}$ \\
\hline Modulation & $\begin{array}{c}\text { QPSK, 16 } \\
\text { QAM, } \\
\text { 64QAM }\end{array}$ & Duplexing & $\begin{array}{c}\text { FDD, TDD, } \\
\text { half Duplex } \\
\text { FDD }\end{array}$ \\
\hline $\begin{array}{c}\text { Downlink } \\
\text { peak data } \\
\text { rate }\end{array}$ & $100 \mathrm{Mbps}$ & $\begin{array}{c}\text { Multiple } \\
\text { Access }\end{array}$ & $\begin{array}{c}\text { OFDMA } \\
\text { (Downlink) }\end{array}$ \\
\hline $\begin{array}{c}\text { Uplink peak } \\
\text { data rate }\end{array}$ & $50 \mathrm{Mbps}$ & $\begin{array}{c}\text { Multiple } \\
\text { Access }\end{array}$ & $\begin{array}{c}\text { SC FDMA } \\
\text { (Uplink) }\end{array}$ \\
\hline Antena & Mimo 2x2 & Bandwidth & $1.4-20 \mathrm{Mhz}$ \\
\hline $\begin{array}{c}\text { Scheduling } \\
\text { Algorithm }\end{array}$ & Frane Level Schedule (FLS) dan Log Rule \\
\hline
\end{tabular}

\subsection{Arsitektur LTE}

Jaringan LTE dirancang untuk tujuan mendukung trafik packet switching dengan mobilitas tinggi, QoS, dan latency yang kecil. Pendekatan packet switching ini memperbolehkan semua layanan termasuk layanan voice menggunakan koneksi paket. Oleh karena itu pada arsitektur jaringan LTE dirancang sesederhana mungkin, yaitu hanya terdiri dari dua node yaitu eNodeB dan mobility management entity / gateway (MME/GW).

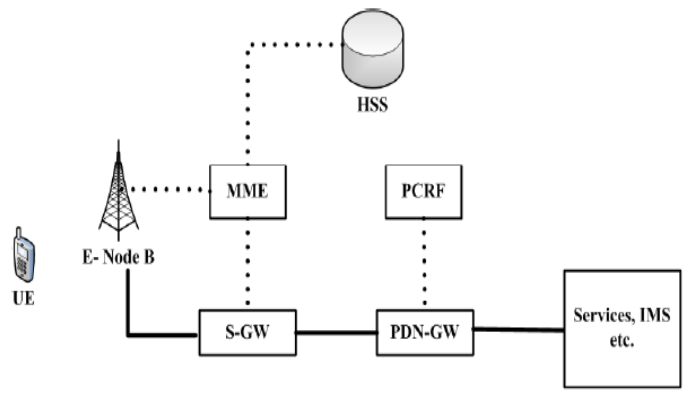

Gambar 2. Arsitektur Dasar Jaringan LTE ${ }^{[11]}$ 
Elemen dasar arsitektur jaringan LTE pada Gambar 2 yaitu:

\subsubsection{UE (User Equipment)}

Merupakan perangkat / terminal radio yang digunakan user untuk menghubungkan jaringan LTE. UE pada LTE tidak berbeda dengan UE pada Universal Mobile Telecommunications System (UMTS) atau teknologi sebelumnya.

\subsubsection{E-UTRAN}

E-UTRAN dalah eNodeB yaitu evolusi dari Radio Access Network (RAN) dan Radio Network Controller (RNC) yang keduanya terdapat di teknologi sebelum LTE. Fungsi eNodeB yaitu untuk radio resource management, mengontrol / mengawasi pengiriman, penerimaan sinyal, berperan dalam autentikasi, dan mengatur scheduling.

\subsubsection{EPC / Core Network ${ }^{[2]}$}

1. MME (Mobility Management Entity)

MME dapat dianalogikan sebagai MSC pada teknologi GSM (Global System For Mobile). MME adalah kontrol utama pada jaringan akses LTE. MME berfungsi untuk mengatur handover, yaitu memilih MME lain untuk handover dengan MME lain, atau memilih SGSN untuk handover dengan jaringan 2G/3G.

2. HSS (Home Subscriber Server)

HSS adalah database utama yang ada pada jaringan LTE. HSS adalah sebuah HLR (Home Location Register) yang mengkombinasikan fungsi HLR sebagai database dan AuC sebagai autentikasi.

3. PCRF (Policy and Charging Rules Function)

PCRF menyediakan kebijakan pengaturan dan aliran keputusan untuk pembiayaan / charging.

4. SGW (Serving Gateway)

SGW terdiri dari dua bagian, yaitu 3GPP Anchor dan SAE Anchor. 3GPP Anchor berfungsi sebagai gateway paket data yang berasal dari jaringan 3GPP, sedangkan SAE Anchor berfungsi sebagai gateway jaringan non-3GPP.

5. PDN-GW (Packet Data Network Gateway) PDN-GW berfungsi sebagai penghubung antara teknologi LTE dengan teknologi non
3GPP seperti wifi dan wimax. PDN-GW merupakan level tertinggi pada sistem.

\subsection{Penjadwalan Paket Arah Downlink ${ }^{[3]}$}

Penentuan suatu paket akan dijadwalkan dipengaruhi oleh beberapa informasi yang harus terpenuhi. Informasi ini akan dikombinasikan dengan perhitungan dari bobot matrik tiap algoritma penjadwalan untuk menghasilkan prioritas pada paket. Informasi ialah sebagai berikut:

1. Nilai CQI (Channel Quality Indication) yang dilaporkan oleh user.

2. Nilai QCI (Qos Class Identifier). Berisi tentang parameternya.

3. Resource allocation history, mengetahui jumlah transmisi yang sudah dilaksanakan sebelumnya.

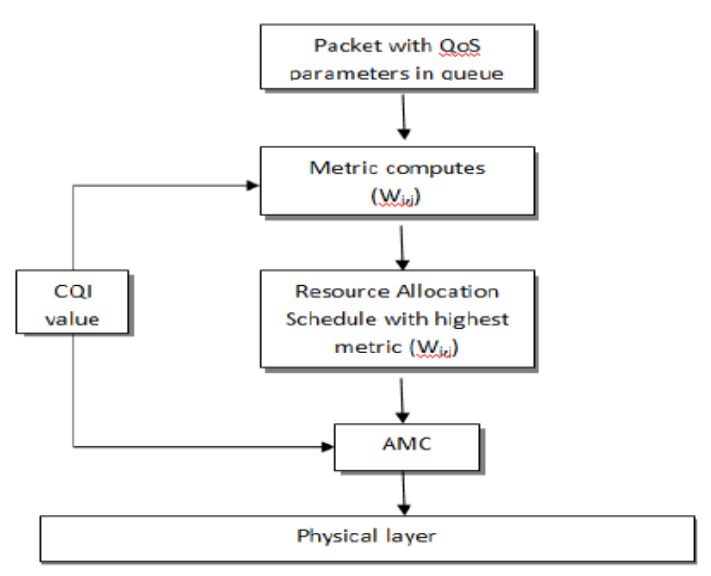

Gambar 3. Blok diagram penjadwalan ${ }^{[3]}$

Berikut ini prosedur dari Gambar 3 penjadwalan paket arah downlink:

1. eNB mendaftar flow yang memiliki paket untuk dikirimkan.

2. Berdasarkan algoritma penjadwalan, dilakukan penghitungan matrik $w_{i, j}$.

3. eNB menetapkan sub-chanel pada antrian yang memiliki nilai matrik tertinggi.

4. eNB menghitung ukuran dari transport block, yaitu kuota dari data yang akan dikirimkan pada lapisan MAC. eNB menggunakan AMC (Adaptive Modulation and Coding) untuk memetakan nilai CQI dengan MCS (Modulation and Coding Scheme). Kemudian, eNB dapat memperoleh ukuran Transport Block (TB) dari MCS yang dipilih yaitu kuota dari data biner pada lapis fisik 
5. Lalu eNB mengambil paket dari flow sesuai dengan kuota yang telah dihitung.

\section{4. $\log$ Rule $^{[3]}$}

Log Rule adalah algoritma penjadwalan yang mampu meminimalkan rata-rata delay dan mampu meminimalkan probabilitas dari jumlah antrian atau seluruh antrian sepanjang buffer yang ada. Ketika antrian user bertambah, log rule mengalokasikan tiap paket dengan cara memperhatikan keseimbangan dari seluruh delay antrian yang bertujuan untuk memaksimalkan throughput. Algoritma ini juga dikenal dengan algoritma delay-optimal.

Untuk paket real time, algoritma penjadwalan ini menghitung nilai matrik yang dimaksud dengan formula persamaan (1).

$$
w_{i, j}=b_{i} \log \left(c+a_{i} W_{i}(t)\right) \times R_{j}(t)
$$

untuk paket non-real time, nilai $\left(c+a_{i} W_{i}(t)\right)$ diabaikan, karena paket non-real time tidak mengharuskan adanya delay parameter $b_{i}=1 \sqrt[1]{R_{i}}, c=1.1$, dan $a_{i}=\frac{5}{d i}$, di adalah waktu delay maksimum paket pada user ke-i.

$W_{i}(t)$ adalah head-of-line (HOL) packet delay antrian user ke-i pada eNB subframe waktu ke-t. $R_{j}(t)$ adalah data rate UE pada sub-channel ke-j.

\subsection{Frame Level Schedule ${ }^{[5]}$}

FLS adalah pola penjadwalan yang terdapat di level teratas dari dua level penjadwalan dibawahnya yakni proportional fair (PF). Algoritma dengan alokasi sumber yang berkompleksitas rendah berdasarkan teori control linear waktu diskret, diimplementasikan di level atas ini. Algoritma ini menghitung jumlah data yang masing-masing sumber realtime harus mentransmisikan ke dalam single frame, untuk memenuhi batas delay. Persamaan berikut (2) menghitung jumlah data yang akan ditransmisikan.

$$
u_{i}(k)=h_{i}(k) * q_{i}(k)
$$

Dimana ui(k) berkorespondensi ke jumlah data yang ditransmisikan selama $k^{\text {th }}$ frame. "*" adalah operator konvolusi waktu diskrit. $q_{i}(k)$ adalah tingkat antrian. Persamaan diatas mengatakan bahwa $u_{i}(k)$ diperoleh dengan menyaring filter sinyal $q_{i}(k)$ melalui saringan linier waktu-invariant dengan respon pulsa $h_{i}(k)$. Berikut penjelasan lebih detail pada Gambar 4 mengenai algoritma FLS.

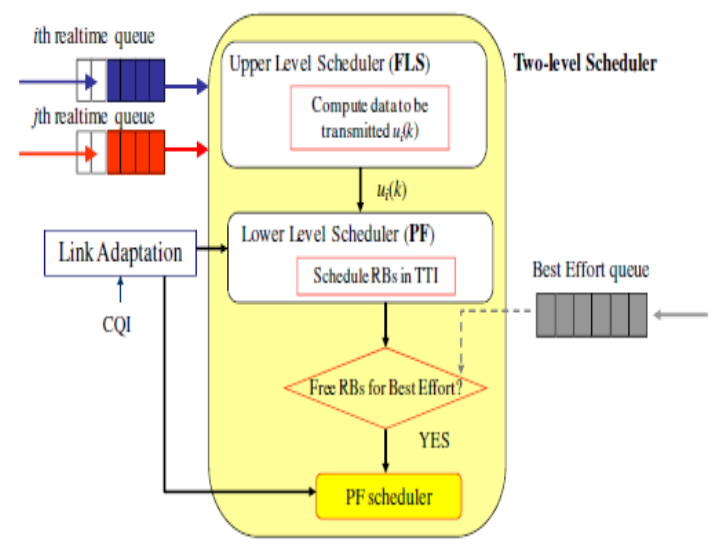

Gambar 4. Blok diagram dua level penjadwalan $^{[5]}$

\section{PEMBAHASAN}

\subsection{Diagram Alir Penelitian}

Pada Gambar 5 pada mulanya penulis mencari referensi yang terkait lalu merumuskan masalah yang mendasari penelitian ini, kemudian mempelajari teori-teori yang mendukung penelitian ini di antaranya pengertian LTE, arsitektur LTE, QoS, penjadwalan, dan algoritma penjadwalan $L o g$ Rule dan FLS. Setelah mempelajari teori tersebut akan dilakukan simulasi dengan skenario multicell dan meliputi system yang digunakan beserta parameter-parameternya, jumlah user, jumlah sel, dan kecepatan pergerakan user. Setelah dilakukan proses ini, maka akan didapat evaluasi dari parameter yang telah ditentukan yaitu berupa QoS nilai dari delay, throughput, fairness, dan packet loss dari kedua algoritma tersebut. Apabila ada data error atau kejanggalan pada data, akan dilakukan pengulangan pengumpulan data. Selanjutnya akan ditinjau dan analisis kualitas hasil QoS skenario pada penjadwalan ini dengan membandingkan standar QoS ITU - T. Setelahnya akan didapatkan kesimpulan dari hasil analisis tersebut.. 


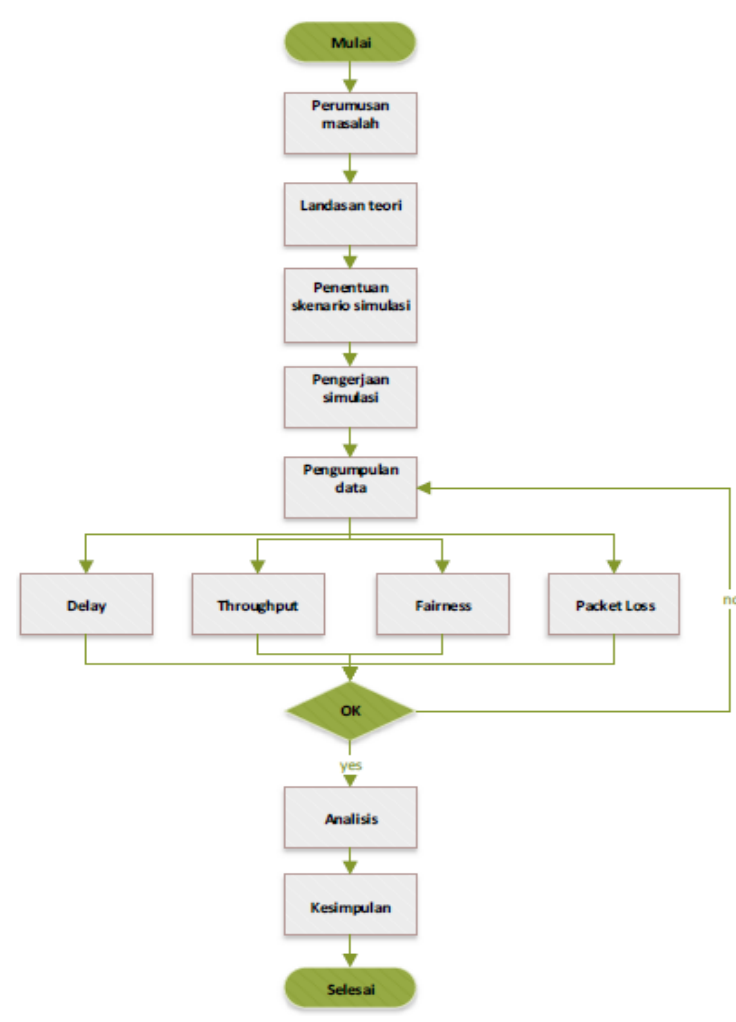

Gambar 5. Diagram alir penelitian

\subsection{Desain simulasi jaringan}

Berikut ini pada tabel 2 adalah konfigurasi yang digunakan pada simulasi, mencakup parameter sistem secara umum, parameter aplikasi yang digunakan oleh user. Parameter sistem secara umum mengikuti konfigurasi default dari simulator. Nilai, jenis dan tipe dari parameter yang ada disesuaikan dengan standar LTE pada Realese- $8^{[6]}$.

Tabel 2. Parameter sistem ${ }^{[2]}$

\begin{tabular}{|c|c|c|c|}
\hline \multicolumn{4}{|c|}{ Parameter System } \\
\hline $\begin{array}{c}\text { Simulation } \\
\text { Time }\end{array}$ & $100 \mathrm{~s}$ & $\begin{array}{c}\text { Flows } \\
\text { Duration }\end{array}$ & $100 \mathrm{~s}$ \\
\hline $\begin{array}{c}\text { Type of } \\
\text { Frame } \\
\text { Structure }\end{array}$ & FDD & $\begin{array}{c}\text { System } \\
\text { Bandwidth }\end{array}$ & $10 \mathrm{MHz}$ \\
\hline Cell Radius & $1 \mathrm{~km}$ & Cell Number & 7 \\
\hline Max Delay & $\begin{array}{l}0.004 \\
\text { detik }\end{array}$ & Mobility Type & $\begin{array}{c}\text { Random } \\
\text { Direction }\end{array}$ \\
\hline $\begin{array}{c}\text { Type of } \\
\text { Scheduler }\end{array}$ & $\begin{array}{l}\text { Log } \\
\text { Rule dan } \\
\text { FLS }\end{array}$ & Handover & YES \\
\hline $\begin{array}{c}\text { Number of } \\
\text { Resource } \\
\text { Blocks }\end{array}$ & 50 & $\begin{array}{l}\text { Sub Carrier } \\
\text { per Resource } \\
\text { Block }\end{array}$ & 12 \\
\hline $\begin{array}{c}\text { Scheduling } \\
\text { Time ( TTI ) }\end{array}$ & $1 \mathrm{~ms}$ & $\begin{array}{l}\text { Sub carrier } \\
\text { spacing }\end{array}$ & $15 \mathrm{kHZ}$ \\
\hline Antena & $\begin{array}{l}\text { MIMO } \\
2 \times 2\end{array}$ & $\begin{array}{l}\text { Sub Channel } \\
\text { Bandwidth }\end{array}$ & $180 \mathrm{kHz}$ \\
\hline
\end{tabular}

\section{ANALISIS}

\subsection{Analisis skenario perubahan jumlah user}

Pada bagian ini disajikan analisis hasil simulasi scenario perubahan jumlah user berdasarkan percobaan-percobaan yang telah dilakukan sebelumnya, dimana simulasi dilakukan pada 25, 50, 75, dan 100 user yang bergerak dengan kecepatan $3 \mathrm{~km} / \mathrm{jam}$ dan tersebar di 7 sel dengan radius masing-masing sel sebesar $1 \mathrm{~km}^{[2]}$

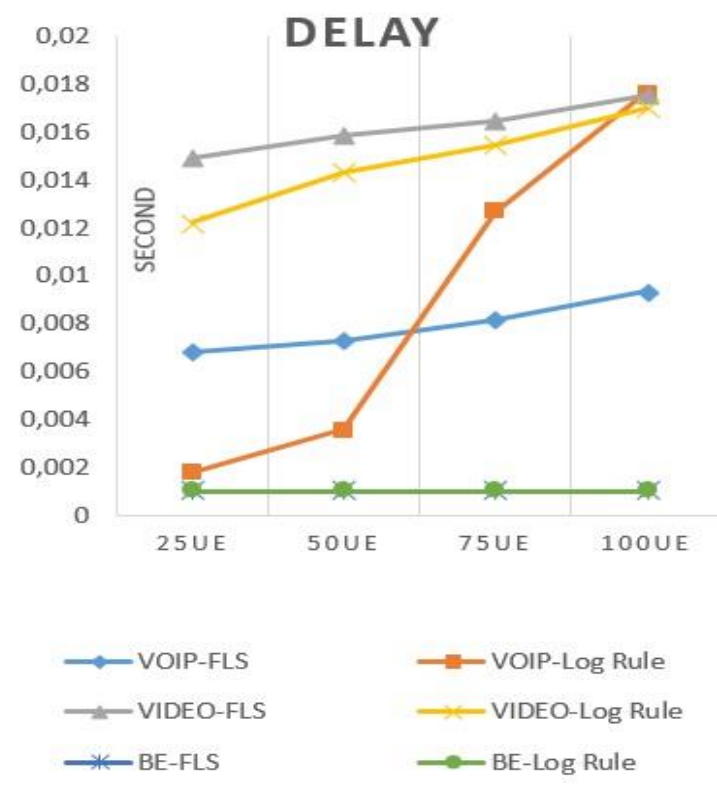

Gambar 6. Delay skenario perubahan jumlah user pada tiap layanan.

Pada gambar 6 secara umum dari dua layanan real time yang disimulasikan yaitu voip dan video, semakin banyak jumlah user yang ditangani, semakin besar pula nilai delay one way yang dihasilkan dikarenakan layanan yang dibangkitkan bersamaan dalam satu kanal. Hal ini juga dipengaruhi oleh prioritas pada setiap layanan, dimana untuk prioritas dalam metode penjadwalan pada urutan pertama adalah voip, kedua video, dan ketiga best effort dalam simulasi ini. Untuk layanan BE merupakan layanan delay tolerant, dikarenakan karakteristik BE yaitu data dan paket yang dikirimkan harus selalu ada maka aliran layanan tersebut pada simulasi ini di menggunakan model infinite buffer, yang mana paket terakhir di transmisikan $1 \mathrm{~ms}$ sehingga delay tidak dapat melebihi nilai tersebut ${ }^{[7]}$. 


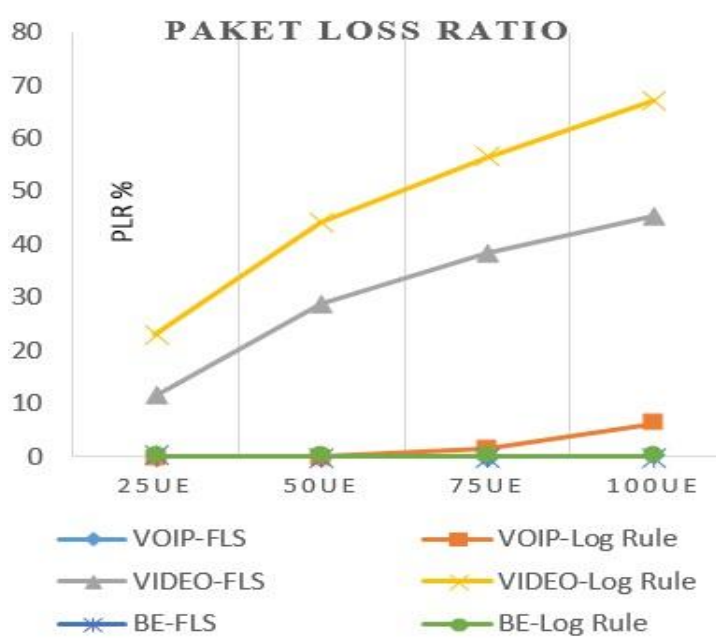

Gambar 7. PLR skenario perubahan jumlah user pada tiap layanan

Pada gambar 7 secara umum dari dua layanan real time yang disimulasikan yaitu voip dan video, semakin banyak jumlah user yang ditangani, semakin besar pula nilai PLR yang dihasilkan. Hal ini disebabkan sumber daya yang kurang memadai sehingga kondisi kanal buruk. Namun pertambahan jumlah user ini tidak berlaku untuk layanan non real time $\mathrm{BE}$, yang menunjukan hasil bervariasi disebabkan kedua algoritma log rule dan FLS memprioritaskan layanan real time.

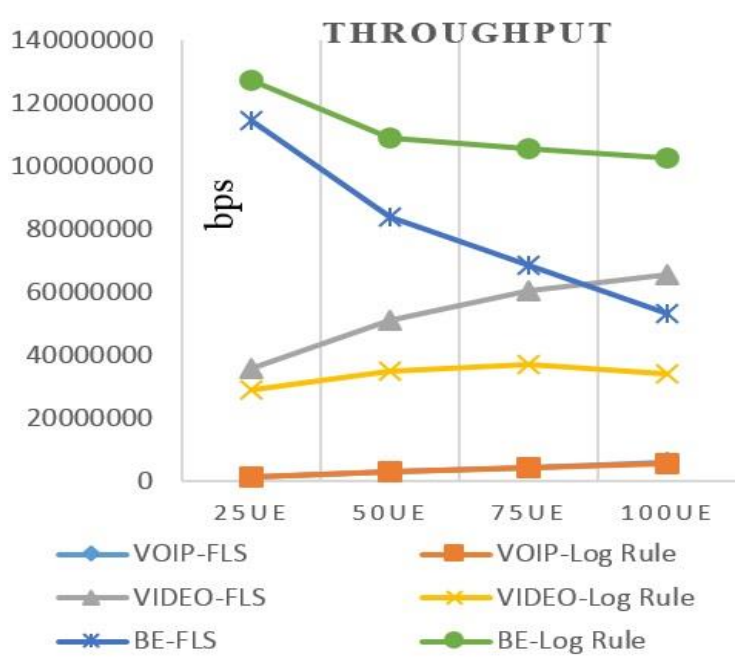

Gambar 8. Throughput skenario perubahan jumlah user pada tiap layanan

Pada gambar 8 secara umum dari dua layanan real time yang disimulasikan yaitu voip dan video, semakin banyak jumlah user yang ditangani, semakin besar pula nilai throughput yang dihasilkan sebab sumber daya yang diberikan masih mencukupi dalam hal ini yaitu bandwidth yang di alokasikan. Namun pertambahan jumlah user ini tidak berlaku untuk layanan non real time BE yang menunjukan penurunan akibat kepadatan trafik yang mempengaruhinya.

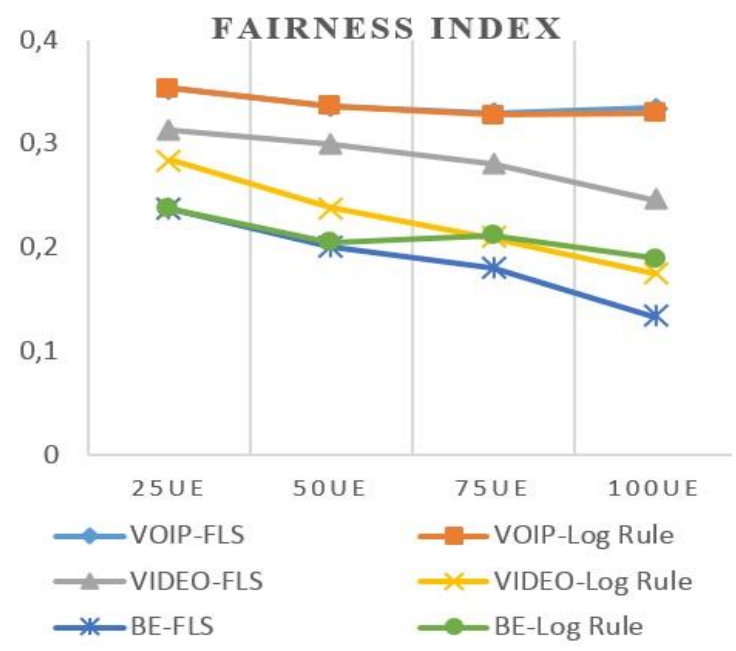

Gambar 9. Fairness Index skenario perubahan jumlah user pada tiap layanan

Pada gambar 9 secara umum menunjukan hasil perbandingan nilai fairness index untuk layanan real time (voip dan video) serta non real time (best effort) menggunakan algoritma penjadwalan Log Rule dan FLS. Dari grafik tersebut terlihat bahwa kedua algoritma seiring bertambahnya jumlah user fairness index yang dihasilkan pun akan semakin menurun. Penurunan keadilan pengalokasian sumber daya bagi user ini disebabkan paket yang berhasil dikirim rendah dan kepadatan trafik.

Namun kedua algoritma tersebut masih jauh dari tingkat standar FI yang ditetapkan ITU-T yaitu 1. Secara keseluruhan algoritma FLS masih memberikan nilai fairness index yang lebih tinggi dibandingkan log rule dikarenakan nilai PLR pada setiap layanan real time atau non real time yang lebih rendah.

\subsection{Analisis skenario perubahan kecepatan user \\ Pada bagian ini disajikan analisis hasil simulasi scenario perubahan kecepatan user menggunakan model Jackes Channel sesuai standar kecepatan pedestrian dan vehicle yang}


di standarkan oleh ITU-T ${ }^{[7]}$, dimana simulasi dilakukan pada 3, 30, dan $120 \mathrm{~km} / \mathrm{jam}$ dengan user sebesar 30, 50 dan tersebar di 7 sel dengan radius masing-masing sel sebesar $1 \mathrm{~km}$.

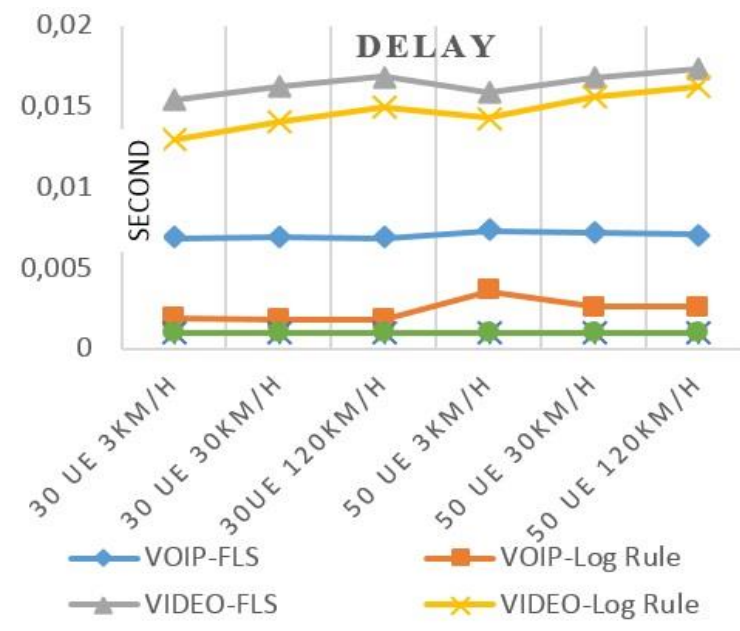

Gambar 10. Delay skenario perubahan kecepatan user pada tiap layanan

Pada gambar 10 secara umum dari dua layanan real time yang disimulasikan yaitu voip dan video, semakin bertambah kecepatan user yang ditangani, semakin besar pula nilai delay yang dihasilkan dihasilkan dikarenakan layanan yang dibangkitkan bersamaan dalam satu kanal. Hal ini juga dipengaruhi oleh prioritas pada setiap layanan, dimana untuk prioritas dalam metode penjadwalan pada urutan pertama adalah voip, kedua video, dan ketiga best effort dalam simulasi ini. Untuk layanan BE merupakan layanan delay tolerant, dikarenakan karakteristik BE yaitu data dan paket yang dikirimkan harus selalu ada maka aliran layanan tersebut pada simulasi ini di menggunakan model infinite buffer ${ }^{[7]}$, yang mana paket terakhir di transmisikan $1 \mathrm{~ms}$ sehingga delay tidak dapat melebihi nilai tersebut ${ }^{[7]}$.

Pada gambar 11 secara umum dari dua layanan real time yang disimulasikan yaitu voip dan video, semakin bertambah kecepatan user yang ditangani, semakin besar pula nilai PLR yang dihasilkan, begitu juga pun untuk layanan non real time $\mathrm{BE}$. Besarnya PLR terjadi akibat beban trafik jaringan meningkat serta sumber daya yang kurang memadai dan algoritma ini hanya memperhitungkan kualitas kanal tanpa memperhatikan batasan kualitas layanan sehingga ketika kualitas kanal menurun, performansi pun ikut menurun serta efek Doppler dan pathloss yang mengganggu pembentukan channel antar terminal user dengan eNodeB.

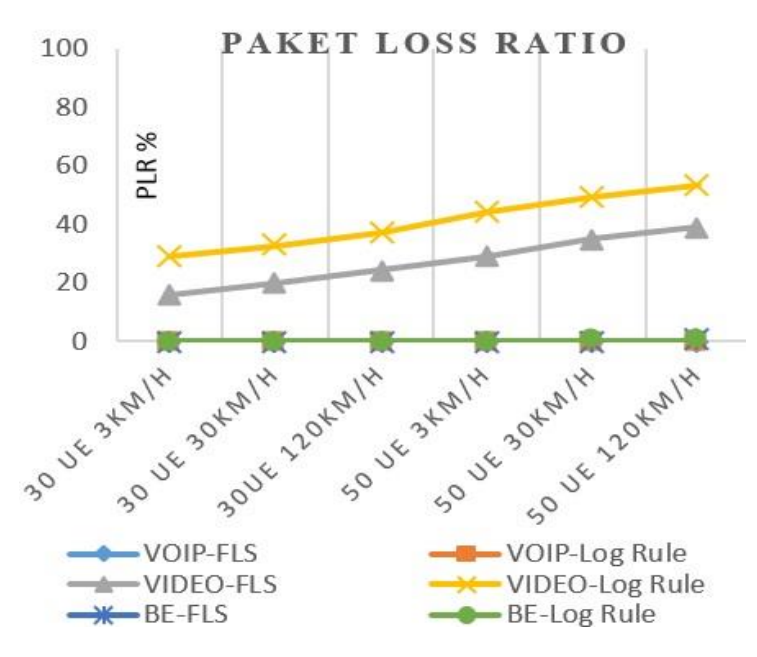

Gambar 11. PLR skenario perubahan kecepatan user pada tiap layanan

Pada gambar 12 secara umum dari dua layanan real time yang disimulasikan yaitu voip dan video, semakin bertambah kecepatan user yang ditangani, semakin menurun nilai throughput yang dihasilkan, begitupun juga untuk layanan non real time seperti $\mathrm{BE}$.

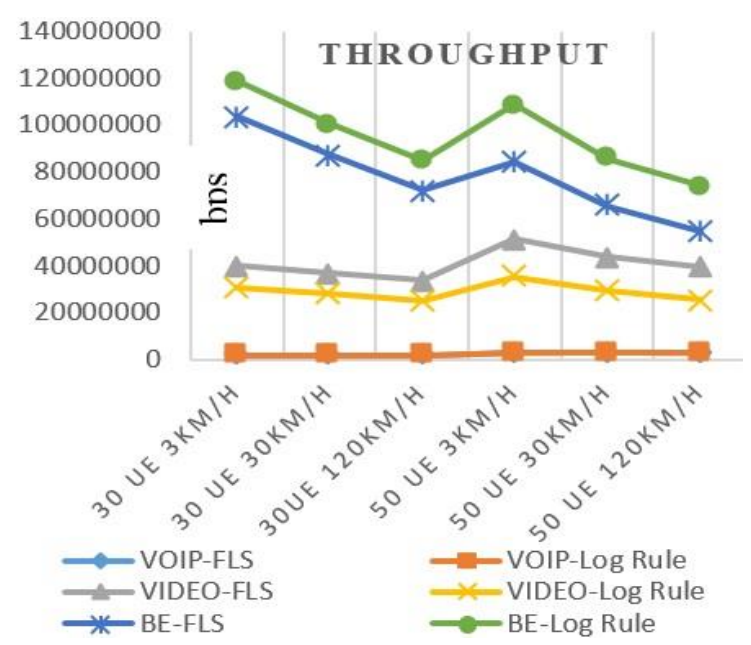

Gambar 12 Throughput skenario perubahan kecepatan user pada tiap layanan

Nilai throughput di pengaruhi oleh available bandwidth serta layanan yang dibangkitkan bersamaan mempengaruhi kondisi kanal. 


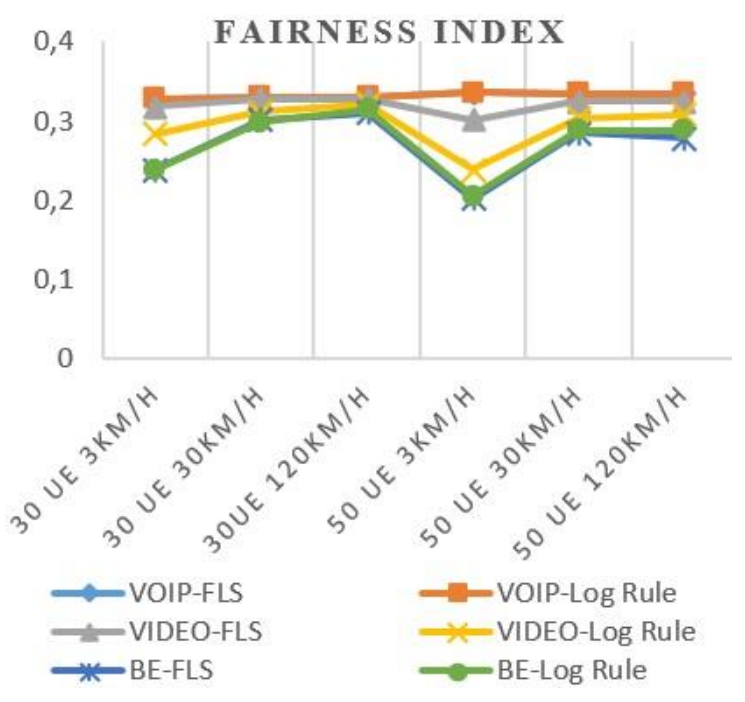

Gambar 13. Fairness Index skenario perubahan kecepatan user pada tiap layanan

Pada gambar 13 secara umum menunjukan hasil perbandingan nilai fairness index untuk layanan real time voip, video dan non real time best effort menggunakan algoritma penjadwalan Log Rule dan FLS. Dari grafik tersebut terlihat bahwa kedua algoritma seiring bertambahnya kecepatan user FI yang dihasilkan pun semakin bertambah. Berbeda dengan ketika user bertambah FI yang di alami terus menurun.

Kenaikan keadilan pengaloksian sumber daya bagi user dengan kecepatan $30 \mathrm{~km} / \mathrm{jam}$ ini disebabkan paket yang berhasil dikirim lebih tinggi dan kepadatan trafik voip rendah karena kondisi kanal yang baik dan rendahnya aktifitas. Sedangkan penurunan yang tidak terlalu signifikan ketika kecepatan $120 \mathrm{~km} / \mathrm{jam}$ disebabkan mobilitas random direction yang di alami user. Hal itu dimanfaatkan sebaik sebaiknya pada penjadwalan log rule yang salah satu karakteristiknya memperhatikan kondisi kanal sehingga memiliki nilai fairness lebih tinggi dibandingkan FLS. Namun kedua algoritma ini masih dibawah batas standar ITUT yang ditentukan untuk FI yaitu 1.

\section{KESIMPULAN}

Dari hasil simulasi dan analisis yang telah dilakukan pada perangkat lunak berbasis open source LTE-SIM dapat diambil beberapa kesimpulan, yaitu:
1. Masing-masing algoritma scheduling memiliki sifat yang berbeda-beda. Terlihat dari beragamnya hasil parameter uji QoS yang didapat kan seperti delay, packet loss ratio, throughput, dan fairness index.

2. Algoritma log rule bertujuan untuk meminimalkan delay, itu terbukti meski jumlah user bertambah ataupun kecepatan user berubah algoritma log rule mampu meminimalkan delay dari kedua layanan real time seperti voip dan video.

3. Algoritma FLS yang hanya memenuhi batas delay dan memaksimalkan throughput, itu terbukti pada hasil simulasi algoritma FLS mampu meningkatkan nilai throughput pada layanan real time dibandingkan log rule.

4. Pada skenario penambahan jumlah user untuk layanan real time voip dan video penggunaan algoritma FLS lebih cocok didasarkan atas nilai PLR yang rendah, throughput yang tinggi, dan tingkat keadilan yang merata untuk setiap layanan.

5. Pada skenario penambahan kecepatan user untuk layanan real time voip dan video kedua algoritma sama-sama memberikan performansi yang kurang optimal karena tingginya delay dan PLR serta turunya throughput. Akan tetapi dalam skenario ini algoritma FLS masih lebih cocok dibandingkan log rule.

6. Untuk layanan non real time seperti BE pada jumlah user bertambah ataupun kecepatan user berubah penerapan kedua penjadwalan $\log$ rule dan FLS kurang cocok. Karena kedua algoritma ini memprioritaskan layanan real time seperti voip dan video.

7. Pada kondisi tertentu penerapan kedua algoritma log rule dan FLS dapat masih digunakan hanya saja untuk layanan realtime voip dan video tergantung tujuan yang ingin dihasilkan.

\section{DAFTAR PUSTAKA}

[1] Stefano, R. (2014). Analisis Perbandingan Kinerja Algoritma Penjadwalan EXP/PF, PF dan FLS Kasus Single Cell pada Jaringan LTE. Repository

[2] Amatullah, S. K. (2012). Analisis Perbandingan Algoritma Penjadwalan PF dan MLWDF Pada Kasus Multicell Jaringan Long Term Evolution. 
[3] Setyawan, A. B. (2012). Analisis Perfomansi Algoritma Penjadwalan: Log Rule dan Exponential Rule pada Jaringan LTE.

[4] Sari, E. P. (2011). Analisis performansi penjadwalan paket pada jaringan lte (long term evolution) arah downlink untuk mendukung layanan triple play.

[5] Piro.G,A.B. (2010). Two - level downlink scheduling for real time multimedia services in LTE networks. IEEE TRANS. VEH. TECHNO. Vol. 13, No. 5.

[6] Overview of 3GPP Release 8 V0.3.3 (2014-09) Diambil dari: http://www.3gpp.org/ftp/Information/ WORK_PLAN/Description_Releases/ Rel-08_description_20140924.zip

[7] Piro.G, A. B. (2010). Simulating LTE Cellular System : an Open Source SFramework\|l. IEEE TRANS. VEH. TECHNOL.

[8] Biswapratapsingh Sahoo. 2013. Performance Comparison of Packet Scheduling Algorithms for Video Traffic in LTE Cellular Network. International Journal of Mobile Network Communications \& Telematics IJMNCT) Vol. 3, No.3, June 2013

[9] Chapter Bab II. (s.f.). Diambil dari: http://www.google.com/url?sa=t\&rct=j $\& \mathrm{q}=\&$ esrc $=$ s $\&$ source $=$ web $\& \mathrm{~cd}=7 \& \mathrm{ved}=$ 0CDoQFjAG\&url=http $\% 3 \mathrm{~A} \% 2 \mathrm{~F} \% 2 \mathrm{Fre}$ pository.usu.ac.id\%2Fbitstream $\% 2 \mathrm{~F} 123$ $456789 \% 2 \mathrm{~F} 29936 \% 2 \mathrm{~F} 4 \% 2 \mathrm{FChapter} \% 2$ 520II.pdf\&ei=ygZaVND6NYyOuASHr oHgAQ\&usg=AFQjCNGGVhf 1GwlSmHloiLP_BIsI-7iZQ\&cad=rja.

[10] Giuseppe, PiroLTE. LTE Simulator. Diambil dari:

www.telematics.poliba.it/index.php/en/lt e-sim (2011).

[11] Prasanna, G. R. (2012). Voice Over LTE.

[12] Suryaman, B. (2010). Perbandingan Perfomansi Algoritma Penjadwalan Round Robin, Maximum C/I dan Proportional Fair dengan Menggunakan HARQ pada Sistem 3GPP LTE.

\section{Biodata Penulis}

Ridwan, lahir di Jakarta tanggal 24 Agustus 1993, mahasiswa Teknik Telekomunikasi Fakultas Teknik Elektro Universitas Telkom.
Indrarini Dyah Irawati, ST., MT. Dosen D3 Teknik Telekomunikasi Fakultas Ilmu Terapan Universitas Telkom. Sebagai dosen di Universitas Telkom, saat ini aktif melakukan riset dan publikasi mengenai wireless sensor network, software define network serta compressive sensing.

Ridha Muldina Negara, ST., MT. Dosen S1 Teknik Telekomunikasi Fakultas Teknik Elektro Universitas Telkom. Sebagai dosen di Universitas Telkom saat ini aktif di Kelompok Keahlian Jaringan Multimedia, saat ini aktif melakukan riset dan publikasi mengenai VANET, software define network serta standar IEEE 802.11 ah. 